\title{
Soybean - New Fertilization Opportunities and Uses in the Food, Feed and Industry Sector
}

\author{
Ioanna KAKABOUKI, Eleni KARAGIANNI, Antigolena FOLINA, Charikleia ZISI, Stavros ARACHOVITIS, \\ Stella KARYDOGIANNI, Konstantia BALLA, Maria CHEINOPOROU, Dimitrios BILALIS* \\ Agricultural University of Athens, School of Agriculture, Engineering and Environmental Sciences, \\ Department of Crop Science, Laboratory of Agronomy, 75 Iera Odos St., 11855 Athens, Greece \\ *corresponding author: bilalis@aua.gr
}

BulletinUASVM Horticulture 77(2) / 2020

Print ISSN 1843-5254, Electronic ISSN 1843-5394

DOI:10.15835/buasvmcn-hort: 2020.0054

\begin{abstract}
Soybean (Glycine max) is one of the most important species of the Fabaceae family worldwide, with many and varied uses, such as food, feed and industry sector. The aim of this study was to evaluate the effect of urea fertilizers in comparison with the new types of fertilizers on the agronomic and quality characteristics of soybean. A field experiment was carried out in the experimental field of the Agricultural University of Athens. The experiment was set up in Randomized Complete Block Design, with 4 treatments (control, $100 \mathrm{~kg} \mathrm{ha}^{-1}$ urea, $100 \mathrm{~kg} \mathrm{ha}^{-1} \mathrm{urea}$ with urease and nitrification inhibitors and $75 \mathrm{~kg}$ urea with urease and nitrification inhibitors) and 3 replications. There were studied several plant agronomic characteristics such as plant height, leaf area index and seed yield, as well as the seed protein content. According to the results, the agronomic and quality characteristics were affected significantly by treatments. To sum up, soybean is a crop for which there is room in Greece for cultivation, for a variety of uses.
\end{abstract}

Keywords: Soybean, human nutrition, urea, nitrogen inhibitors, seed yield, protein content

\section{Introduction}

Soybean (Glycine max) is a plant that belongs to the Fabaceae family. Soybean is one of the most important species of this family worldwide, with many and varied uses, such as food, feed and industry sector. Soybeans come from East Asian countries. The most important characteristic of legumes is its ability to nitrogen fixation. Although soybean fixes nitrogen, several studies have reported that it responds positively to the application of nitrogen fertilizers (Salvagiotti et al., 2008).

Nitrogen is the key factor for plant growth and yield, in soybean crop (Kakabouki et al., 2020). Soil nitrogen comes from organic and inorganic fertilizers. The most commonly used inorganic fertilizer is urea. Urea and urea-based fertilizers have many advantages over others, but they also have certain disadvantages. One of the most important disadvantages is the loss of nitrogen in the environment. Therefore, new types of fertilizers with inhibitors are now coming to minimize these losses. The inhibitors mostly used are the urease inhibitor, thiophosphorictriamide (NBPT) and the nitrification inhibitor, dicyandiamide (DCD) (Li et al., 2020). In addition, the most important advantage of the new fertilizer types in terms of plant cultivation is the improvement of the synchronization of supply and demand.

The aim of the present study was to evaluate the response of agronomic characteristics, yield and protein content of soybean in inorganic fertilization, in comparison with new type of fertilizers with inhibitors and to evaluate the optimal fertilizer rate with inhibitors. 


\section{Materials and methods}

A soybean (Glycine max Merr.) field experiment was carried out in the experimental field of the Agricultural University of Athens (Latitude: $37^{\circ} 59^{\prime} 1.70^{\prime \prime} \mathrm{N}$, Longitude: $23^{\circ} 42^{\prime} 7.04^{\prime \prime}$ E, Altitude: $29 \mathrm{~m}$ above sea level), during the summer of 2020 . The soil was clay loam (CL), with organic matter $2.37 \%$ and $\mathrm{pH}$ 7.29. The meteorological data, mean temperature and precipitation, for the experiment period are presented in Figure 1.

The experiment was set up according to Randomized Complete Block Design (RCBD), with 4 treatments (control, $100 \mathrm{~kg} \mathrm{ha}^{-1}$ urea, 100 $\mathrm{kg} \mathrm{ha}^{-1} \mathrm{U}+\mathrm{NI}+\mathrm{UI}$ and $75 \mathrm{~kg} \mathrm{ha}^{-1} \mathrm{U}+\mathrm{NI}+\mathrm{UI}$ ) and 3 replications. The fertilizers used were urea, Nutri Plus 40-0-0, and ALZON neo-N, urea (N 46.3\%) (U) with nitrification (MPA 0.07\%) (NI) and urease (2-NPT 0.035\%) (UI) inhibitors, by Teofert. The variety of soybean used was 'Bahia'. Total experimental area was $120 \mathrm{~m}^{2}$, and each plot was $10 \mathrm{~m}^{2}$. The distance between the planting rows was $0.5 \mathrm{~m}$. The sowing and harvest dates were 6 May 2020 and 8 September 2020 respectively. The measurements carried out in this study concerned the agronomic and quality characteristics of the plants.There were measured the plant height $(\mathrm{cm})$ in 5 different days after sowing (DAS), the 1000 seed weight (g), the Leaf Area Index (LAI) in 3 different DAS using a SunScan (Delta-T Devices Ltd) and the seed yield ( $\left.\mathrm{kg} \mathrm{ha}^{-1}\right)$. As for the quality characteristics in the present study it was determined the seed protein content (\%).
Analysis of variance was carried out on data using the Statistica (Stat Soft, 2011) logistic package as a Completely Randomized Design. The significance of differences between treatments was estimated using LSD test and probabilities equal to or less than 0.05 considered significant.

\section{Results and discussion}

According to Table 1, all plant agronomic characteristics were affected significantly by the treatment. The greatest plant height value was $58.28 \mathrm{~cm}$ on the treatment in which were applied $75 \mathrm{~kg} \mathrm{ha}^{-1}$ urea with double inhibitors.

This can be explained by the fact that during the treatment with urea with double inhibitors the supply of nitrogen was gradual, as a result of which the plants absorbed nitrogen throughout their growth cycle. On the other hand in control was recorded the lowest height of soybean plants, almost $34 \mathrm{~cm}$ lower than the highest value. Regarding the weight of 1000 seeds, the highest value, was almost $50 \mathrm{~g}$ higher than the lowest, and was shown on the treatment with $75 \mathrm{~kg} \mathrm{ha}^{-1}$ urea with double inhibitors, as well as the leaf area index (LAI) (Tab. 1).

In addition, according to Zacherl and Amberger (1990), diacyandiamide, the nitrification inhibitor used in this study, affects neither the growth nor the respiration of bacteria. Regarding the urease inhibitor, there are no data in the literature yet on their effects on nitrogen-fixing bacteria. Yield in seed was the highest on the lower amount

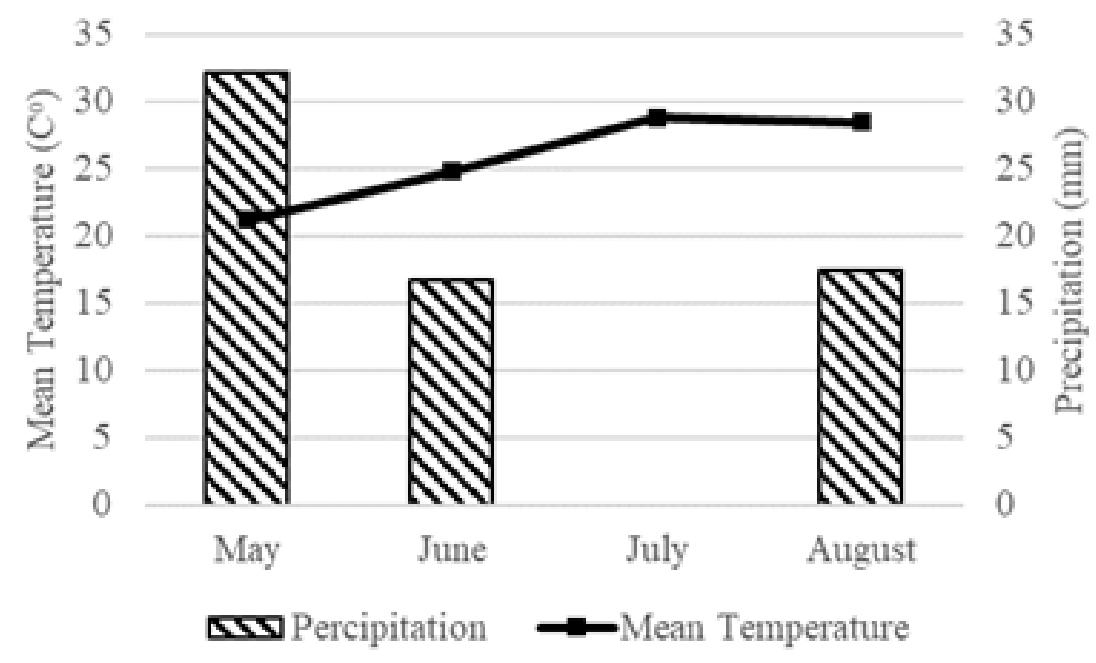

Figure 1. Meteorological data, mean month temperature and precipitation for experimental site during the growing period 
Table 1. Agronomic and quality characteristics as effected by fertilizer treatments

\begin{tabular}{cccccc}
\hline Treatment & $\begin{array}{c}\text { Plant height } \\
\text { (cm) }\end{array}$ & $\begin{array}{c}\text { 1000 seed } \\
\text { weight (g) }\end{array}$ & LAI & $\begin{array}{c}\text { Seed yield } \\
\text { (kg ha-1) }\end{array}$ & $\begin{array}{c}\text { Seed protein } \\
\text { content (\%) }\end{array}$ \\
\hline Control & $24.64^{\mathrm{a}}$ & $115.23^{\mathrm{a}}$ & $1.27^{\mathrm{a}}$ & $3,937.00^{\mathrm{a}}$ & $35.77^{\mathrm{a}}$ \\
\hline $\mathrm{Urea}^{\mathrm{b}}$ & $42.30^{\mathrm{ab}}$ & $159.50^{\mathrm{b}}$ & $2.00^{\mathrm{b}}$ & $5,598.33^{\mathrm{b}}$ & $37.63^{\mathrm{b}}$ \\
\hline $\begin{array}{c}100 \mathrm{~kg} \mathrm{ha}^{-1} \\
(\mathrm{U}+\mathrm{NI}+\mathrm{UI})\end{array}$ & $55.20^{\mathrm{b}}$ & $163.53^{\mathrm{b}}$ & $2.07^{\mathrm{b}}$ & $5,634.33^{\mathrm{b}}$ & $38.83^{\mathrm{b}}$ \\
\hline $\begin{array}{c}75 \mathrm{~kg} \mathrm{ha}^{-1} \\
(\mathrm{U}+\mathrm{NI}+\mathrm{UI})\end{array}$ & $58.28^{\mathrm{b}}$ & $164.00^{\mathrm{b}}$ & $2.10^{\mathrm{b}}$ & $5,640.00^{\mathrm{b}}$ & $41.28^{\mathrm{c}}$ \\
\hline $\mathrm{F}_{\text {treatment }}$ & $3.86^{*}$ & $51.88^{* * *}$ & $40.45^{* * *}$ & $3,681.80^{* * *}$ & $21.65^{* *}$ \\
\hline
\end{tabular}

Note: F-test ratios are from ANOVA. Different letters within a column indicate significant differences according to LSD test $(\alpha=0.05)$. Significance levels: ${ }^{*} \mathrm{p}<0.05 ;{ }^{* *} \mathrm{p}<0.01 ;{ }^{* * *} \mathrm{p}<0.001 ; \mathrm{ns}$, not significant $(\mathrm{p}>0.05)$.

of urea with inhibitors. It is worth noting that the difference between the highest and the lowest (control) value was almost $1,700 \mathrm{~kg} \mathrm{ha}^{-1}$. Similar results are presented in several studies in which is recorded that the combination with the nitrification and urease inhibitor is able to increase crop yields (Abalos et al., 2014).

In terms of the protein content as it shown in Table 1, its content in seeds was affected statistically significant by the treatments. More specifically, the protein level in the seeds which were fertilized with $75 \mathrm{~kg} \mathrm{ha}^{-1}$ urea with double inhibitors was almost $10 \%$ higher than in the control treatment. According to Bellaloui et al. (2020), nitrogen application resulted in higher protein content in soybean.

\section{Conclusion}

Based on the results of this study, urea with double inhibitors was found to be more beneficial for soybean cultivation than other treatments. More specifically, the ideal amount of urea with double inhibitors for soybean cultivation, in Greek conditions is $75 \mathrm{~kg} \mathrm{ha}^{-1}$, in order to lead to the best quantity and quality of the product obtained. Therefore, soybean is a crop for which there is room in Greece for cultivation, for various uses.

\section{References}

1. Abalos D, Jeffery S, Sanz-Cobena A, Guardia G, Vallejo A (2014). Meta-analysis of the effect of urease and nitrification inhibitors on crop productivity and nitrogen use efficiency. Agriculture, Ecosystems \& Environment, 189: 136-144.

2. Bellaloui N, McClure AM, Mengistu A, Abbas HK (2020). The Influence of Agricultural Practices, the Environment, and Cultivar Differences on Soybean Seed Protein, Oil, Sugars, and Amino Acids. Plants, 9: 378.

3. Kakabouki I, Folina A, Zisi Ch, Karydogianni S (2020). Fertilization expression via nitrogen indices in soybean crop under two system tillage. Notulae Botanicae Horti Agrobotanici Cluj-Napoca, 48(2): 799-813.

4. Li Y, Mingfang H, Tenuta M, Ma Z, Gui D, Li X, Zeng F, Gao X (2020). Agronomic evaluation of polymercoated urea and urease and nitrification inhibitors for cotton production under drip-fertigation in a dry climate. Scientific Reports, 10: 1472 .

5. Salvagiotti F, Cassman KG, Specht JE, Walters DT, Weiss A, Dobermann A (2008). Nitrogen uptake, fixation and response to fertilizer $\mathrm{N}$ in soybeans: A review. Field Crops Research, 108(1): 1-13.

6. Zacherl B, Amberger A (1990). Effect of nitrification inhibitors on $\mathrm{N}$-fixing bacteria Rhizobium leguminosarum and Azotobacter chroococcum. Fertilizer Research, 22(3): 137-139. 